Review Article

\title{
An Overview of Recent Advances in the Mesozoic-Palaeogene Vertebrate Paleontology in the Context of India's Northward Drift and Collision with Asia
}

\author{
G V R PRASAD ${ }^{1, *}$ and S BAJPAI ${ }^{2}$ \\ ${ }^{1}$ Department of Geology, Centre for Advanced Studies, University of Delhi, Delhi 110 007, India \\ ${ }^{2}$ Birbal Sahni Institute of Palaeosciences, 53 University Road, Lucknow 226 007, India
}

(Received on 10 April 2016; Accepted on 20 May 2016)

\begin{abstract}
This review article summarizes the recent work done in India on fossil vertebrates from the Mesozoic-early Paleogene interval, with focus on the past five years. Advances made during this period highlight the importance of India's vertebrate fossil record in our understanding of the origin and evolutionary history of several vertebrate groups and the dynamics of intercontinental faunal dispersal and vicariance, especially in the context of India's former position in the Gondwanaland and its subsequent separation from the different Gondwana landmasses as it moved northward to finally collide with Asia in the early Paleogene. These studies have led to a better understanding of the mode of evolution of tetrapods on the drifting Indian plate and provide independent constraints to test the traditional models favouring India's physical isolation from all other landmasses, especially during the late Cretaceous phase of its northward drift. Recent data points to faunal interchanges between India, Africa and Europe at or near the K-Pg boundary and also suggests that the Indian landmass was the centre of origin/early evolution for several orders of modern mammals, including cetaceans (whales), perissodactyls (horses, tapirs) and primates.
\end{abstract}

Keywords: Cretaceous; Palaeogene; Mammals; Evolution; Palaeobiogeography

\section{Introduction}

The Indian subcontinent, which was part of the Gondwanaland in the geological past, had a long history of break-up, isolation and rapid northward journey before its collision with the Asian mainland. The historical biogeography of India is, thus, can be divided into four distinct phases, viz., pre-drift phase, early drift phase, late drift phase and pre-collision and collision phase. In a classic paper, Krause and Maas (1990) hypothesized that primates, artiodactyls, perissodactyls and hyaeonodontids evolved on a Noah's Ark like Indian plate during its northward flight, and subsequently dispersed out of India into Asia. This laid the foundation for the later 'Out-of-India' dispersal hypothesis of Bossuyt and Milinkovitch (2001) which was based on molecular phylogeny of modern ranid frogs. In this context, many questions arise regarding the evolution of biota on a drifting landmass - Was there an endemic evolution of biota in response to a long period of isolation? Were there biotic interchanges between India and other landmasses during the former's physical isolation? Is there any fossil evidence for 'Out-of-India' dispersal hypothesis? Therefore, to understand the response of continental vertebrate fauna to India's northward movement from a pre-drift southern high latitude position to its current post-collision position, one must examine the Mesozoic - Palaeogene fossiliferous deposits of the Indian subcontinent. In this short review, the work done in the last five years in different sedimentary basins (Gondwana basins, Cauvery basin, Deccan volcanic province, Tertiary basins of western India and NW Himalaya) representing various phases of India's northward journey is discussed. The main objective of this review is to summarize the recent work done in India in the field of vertebrate palaeontology, especially during the past five years (2011-2015).

\footnotetext{
*Authorfor Correspondence: E-mail: guntupalli.vrprasad@gmail.com
} 


\section{Recent Finds}

\section{Pre-drift Phase}

During the pre-drift phase India was positioned in the southern high latitudes in the neigbourhood of Africa, Antarctica and Australia and the vertebrate fossil record for this phase has been fairly well documented from the Lower Triassic Panchet Formation, the Upper Triassic Maleri and Tiki formations and the Lower Jurassic Kota Formation of peninsular India through the efforts of researchers from the Geological Studies Unit, Indian Statistical Institute and the Geological Survey of India. Among the lower Triassic rocks of India, the Panchet Formation of Damodar valley is long known for its dicynodont fauna. The latest report of three dicynodot skulls, two belonging to Lystrosaurus cf. curvatus and the third one representing $L$. declivis, indicated that the Lystrosaurus fauna of India is correlatable with that of the upper part of Balfour Formation and the overlying Katberg Formation (Early Triassic) of the Barroo Basin, South Africa in its diversity and age (Gupta and Das, 2011). More recently, a graveyard of rhynchosaur, an archosauromorph reptile, interpreted as representing a mass mortality event during sudden flooding was discovered in the Upper Triassic (Early Carnian) Tiki Formation of South Rewa Gondwana basin (Mukherjee and Ray, 2012). The rhynchosaur bones from this site were later identified as belonging to a new species Hyperodapedon tikiensis, possibly the most advanced species among rhynchosaurs that represents a postural evolution intermediate between sprawling and erect postures (Mukherjee and Ray, 2014). Contrary to the long held view that archosauromorphs were slow growing, bone histology of $H$. tikiensis revealed these animals were growing fast during juvenile and sub-adult stages (Mukherjee, 2015). The Tiki Formation has also yielded lower jaws of a new large traversodontid cynodont Ruberodon roychowdhuri Ray, 2015. Phylogenetic analysis of $R$. roychowdhuri nested it as a sister taxon of Exaeretodon statisticae within the clade containing Gomphodontosuchus, Menadon, Scalenodontoides, Protuberum, Ruberodon and Exaeretodon (Ray, 2015). The new taxon allows the correlation of the Tiki Formation with the lower part of the Upper Triassic Maleri Formation, the Isalo II Beds of Madagascar and the upper part of Santa Maria Formation. Novas et al. (2011) described a new dinosaur fauna represented by two plateosaurian taxa (Nambalia roychowdhuri, Jaklapallisaurus asymmetrica), a guaibasaurid and two basal dinosauriformes from the Upper Triassic Maleri Formation (Norian - earliest Rhaetian). From the Lower Dharmaram Formation (Norian-Rhaetian age), Novas et al. (2011) have documented basal sauropodomorph and neotheropod remains. This has substantially improved the diversity of Late Triassic dinosaur fauna of India. Further, the study of Novas et al. (2011) has demonstrated that the rhynchosaur dominated Lower Maleri Formation is poor in dinosaurs as compared to their high diversity in coeval beds from South America. On the other hand, the archosaur dominated Upper Maleri and Lower Dharmaram formations yielded taxonomically diverse basal sauropodomorphs as was the case with contemporaneous beds from South America and Europe. The latter radiation post-dating Ischigualastian extinction event indicates that the early radiation of dinosaurs was not synchronous across the world. As expected, the Triassic continental vertebrate fauna of India demonstrates close biogeographic affinities with both Gondwanan and Laurasian continents because of the existence of a single supercontinent Pangaea at that time.

The split between Africa and India - Madagascar block took place during the Jurassic Period ( 150 160 Ma ago), (see Prasad and Sahni, 1999; Chatterjee et al., 2013). The Kota Formation of PranhitaGodavari valley is one of the few Early Jurassic vertebrate yielding horizons in the world and has been a source of many vertebrate groups including fishes, amphibians (personal observations of the first author), crocodiles, turtles, rhynchocephalians, lizards, dinosaurs, and mammals (see Prasad and Manhas, 2007 for references). Dinosaurs include two nearly complete skeletons (Jain et al., 1979; Yadagiri et al., 1979; Bandyopadhyay et al., 2010). A more detailed description of the skeletal elements of the briefly described sauropod dinosaur Barapasaurus tagorei (Jain et al., 1979) and some other specimens that have not been studied earlier was provided by Bandyopadhyay et al. (2010). Phylogenetic analysis of the various skeletal characters led Bandhyopadhyay et al. (2010) to conclude that Barapasaurus is more derived than Kotasaurus, the second dinosaur taxon of the Kota Formation, but it is more basal to Vulcanodon. The upper part of the Dharmaram 
Formation of the Pranhita-Godavari valley has also yielded Early Jurassic vertebrates but these are mainly restricted to skeletal remains of two taxa of basal sauropodmorphs (Kutty et al., 2007). Outside the Gondwana sedimentary basins of India, footprints of theropod dinosaurs (Eubrontes cf. giganteus, Grallator tenuis) have been documented from the marine Lower Jurassic Thaiat Member of the Lathi Formation, Jaisalmer basin, western India (Pienkowski et al., 2015). The mammalian fauna from the Kota Formation assumes great significance as it is expected to reveal the diversity and evolution of early mammals in the former Gondwanaland at a time when the continents began to breakup. Until now, the early mammal groups represented by symmetrodonts, triconodonts, docodonts and multituberculates have been documented from Kota Formation (Parmar et $a l ., 2013$ for references). In fact, the multituberculate mammal Indobaatar zofiae from the Kota Formation is possibly the oldest member of this predominantly Laurasian group (Parmar et al., 2013). More recently, Parmar et al. (2015) indicated that the mammalian fauna of the Kota Formation is highly diverse consisting of the Gondwanan australosphenidans, haramiyidans, and possible dryolestids, besides the already known symmetrodonts, triconodonts, docodonts and multituberculates. In the former Gondwanaland, besides India, Jurassic mammals are known from South America and Africa. However, in the latter two landmasses, the mammalian diversity is extremely low, with only australosphenidans and dryolestids recorded from South America, and haramiyidans and therians known from Africa. In comparison, the diversity of Indian Jurassic mammals is very high, as diverse as that of Laurasia. This implies very close biogeographic connections between India and Laurasia and biogeographic partitioning of Gondwanan continents during the Jurassic.

\section{Early Drift Phase}

During the early drift phase, the Indo-Madagascar block was separated from the Australia-Antarctica block at about 120-130 Ma ago (see Prasad and Sahni, 1999; Chatterjee et al., 2013) which was followed by the inundation of southeastern coast of India and deposition of marine Cretaceous sediments in the Cauvery basin, South India (Veevers et al. 1991). The vertebrate record for the early drift phase of India is poorly documented. The sedimentary rock record for the Early Cretaceous period is represented by the Dalmiapuram and Karai formations of Cauvery basin, the Gangapur Formation of Pranhita-Godavari valley, informally designated east coast Gondwana rocks, and the Rajmahal intertrappean beds. So far, no animal fossils have been reported from the Rajmahal intertrappean beds. Only isolated fish scale impressions are known from the East Coast Gondwana deposits (Bakshi, 1973). The Cretaceous Gangapur Formation has yielded scarce vertebrate fossils consisting of actinopterygian fish teeth (Prasad et al., 2004). In a recent study, Underwood et al. (2011) described a fairly large number of shark teeth (Protosqualus sp., Gladoserratus magnus, ?Notidanodon sp., Cretalamna appendiculata, Dwardius sudindicus, ?Eostriatolamia sp., Squalicorax aff. baharijensis and Cretodus longiplicatus) and a few ichthyosaur teeth representing Platypterygius indicus? from The Albian-Cenomanian Karai Formation. Most of these shark taxa were endemic to India at species level and many of them had an antitropical distribution consistent with the high latitude position of India. Subsequently, durophagous shark teeth belonging to the cosmopolitan Ptychodus decurrens were also documented from the Karai Formation (Verma et al., 2012).

\section{Late Drift Phase}

Two major plate tectonic events occurred during the late drift phase: 1) break-up of India-Seychelles block from Madagascar around 88-90 $\mathrm{Ma}$ ago and 2) eruption of Deccan Traps and separation of India from the Seychelles at about $65 \mathrm{Ma}$ ago. This was also the phase during which the Indian landmass drifted very rapidly at a rate of $15-20 \mathrm{~cm} /$ year (Powell, 1979) until its docking with the southern margin of Asia around 50-55 Ma ago (Patriat and Achache, 1984). Therefore, the vertebrate fauna from the late drift and pre-collision phases is very important for understanding the evolution of life on a landmass migrating rapidly towards the north as a Noah's Ark and the effects of large scale volcanism on life. The sedimentary sequences representing the late drift phase are the Upper Cretaceous (Maastrichtian) Lameta Formation and the Deccan intertrappean beds of Deccan Volcanic Province, and the Upper Cretaceous (Late Maastrichtian) Kallamedu Formation of Cauvery basin. The Lameta Formation and the Deccan intertrappean beds have been extensively studied in 
recent years because of the supposed linkage between Deccan volcanism and the Cretaceous-Palaeogene (K-Pg) boundary mass extinctions (McLean, 1985). As a consequence, the Late Cretaceous biodiversity record of India has improved tremendously in the last three decades (see Prasad and Sahni, 2014 for citations). Currently, the vertebrate fauna from the Lameta Formation and the intertrappean beds is known by 53 species of fishes, 5 species of amphibians, 8 species of lizards, 5 species of turtles, 3 species of crocodiles, 6 species of snakes, 9 species of dinosaurs and 7 species of mammals (Prasad, 2012). The latest report of a partial skeleton of $3.5 \mathrm{~m}$ predatory snake named as Sanajeh indicus (Family Madtsoidae) from the Lameta Formation exposed near Dholi Dungri village in Gujarat and occurring coiled around a dinosaur egg and adjacent to a hatchling skeleton has suggested that this snake frequented sauropod nesting sites and preyed upon hatchling sauropods (Wilson $e t$ al., 2010). In a subsequent publication, Mohabey et al. (2011) described a new species of a madtsoid snake Madtsoia pisdurensis from the Lameta Formation of Pisdura, Maharashtra with close relationship to $M$. madagascarensis from the Late Cretaceous of Madagascar and to M. bai and $M$. composi from the Palaeocene of South America. These authors suggested that as India, Madagascar and South America were well separated from each other by $100-90 \mathrm{Ma}$, the wide distribution of similar taxa in these landmasses indicates their origin and dispersal prior to the separation of these landmasses or that there were some yet to be identified land connections between these southern terranes. Srivastava and Mankar (2015) documented the presence of a single nest of Megaloolithus (sauropod dinosaur) in the Lameta Formation from a geographic site located at the boundary of Amaravati District in Maharashtra and Betul District in Madhya Pradesh, quite far away from the traditionally known nesting sites of Jabalpur, Bagh, Balasinor, and Dongargaon. In a major taxonomic reassessment of the purported large lizard nest found in association with sauropod nests in the Lameta Ghat section of the Lameta Formation at Jabalpur, Srivastava et al. (2015) reassigned it to crocodiles. This is the first record of a crocodile nest from the Late Cretaceous of India. Fernández and Khosla (2015) revisited the parataxonomic classification of the Late Cretaceous dinosaur eggshells of the Megaloolithidae family from the Lameta Formation of India and the Upper Cretaceous Allen Formation, Argentina and synonymized some of the taxa with the pre-existing ones and also erected a new genus Fusioolithus for M. baghensis and synonymized M. pseudomamillare, M. balasinorensis, Patagoolithus salitralensis with Fusioolithus baghensis. Tipo 1c eggshells of Argentina were referred to a new species of Fusioolithus, F. berthei. Since five of the dinosaur oospecies (M. jabalpurensis, M. cylindricus, $M$. megadermus, $F$. baghensis and $F$. berthei) are common to India, South America, Africa and France, Fernández and Khosla (2015) inferred a close phylogenetic relationship between the dinosaur oospecies of these continents and the existence of a terrestrial connection between India and Europe and between the Gondwanan continents. A detailed analysis of Type A sauropod coprolites from the Lameta Formation of Pisdura, Maharashtra revealed the presence of freshwater ostracods, diatoms, charophytes, sponge spicules, probable chrysophytes, gymnosperm tissues, a spore, cuticle and leaf laminae (Khosla et al., 2015). The presence of these plant tissues and microfossil remains in phosphatic coprolites indicates that the producer animals were intentional or passive omnivores.

The latest discoveries from the intertrappean beds have thrown some new light on the origin and evolution of primitive eutherian mammals on insular India. Earlier, based on ankle bone functional morphology, Deccanolestes, the well known Late Cretaceous eutherian mammal from India, was inferred as an euarchontan (Prasad and Godinot, 1994; Smith et al., 2010), the ancestral stock from which primates had originated. However, Prasad et al. (2010) supported by new dental material from the intertrappean beds showed that Deccanolestes is phylogenetically close to Afrodon (Family Adapisoriculidae) known from the Palaeocene rocks of Africa (Gheerbrant and Russell, 1989) and Europe (Russell, 1964). Because of the older age and slightly primitive state of the Indian taxon, they suggested that Deccanolestes originated in India and subsequently dispersed to Africa and Europe close to the K-Pg boundary. In a concurrent publication, based on the study of new postcranial bones (humerus and ulnae), Boyer et al. (2010) confirmed that Deccanolestes was an arboreal mammal, but the morphology of the humerus is intermediate between 
Cretaceous "condylarth" mammals and Cenozoic euarchontans. On the other hand, the humeri attributed to adapisoriculids were considered by them as morphologically intermediate between Deccanolestes and definitive Cenozoic euarchontans. This implies that Deccanolestes is more basal in position with respect to adapisoriculids and euarchontans. If Deccanolestes is accepted as a stem euarchontan, it has far reaching implications for the timing of origin and diversification of placental mammals. It would suggest that euarchontans and hence placental mammals originated before the K-Pg boundary in the Indian subcontinent, Africa or Europe. However, cladistic analysis carried out using both dental and postcranial characters revealed no close phylogenetic relationship between euarchontans and Deccanolestes, suggesting that the latter is not a Cretaceous placental mammal (Goswami et al., 2011). However, this analysis has demonstrated sister group relationship between Deccanolestes and African and European adapisoriculids and pushed them to a more basal position within the cladogram suggesting the existence of 30-45 m.y. ghost lineages for these Gondwanan eutherian mammals. Goswami et al. (2011) also supported faunal interchanges between India, Africa and Europe at or near the KPg boundary. Latest geometric morphometric study of the ankle bones of Deccanolestes showed that its astragalar morphology has no analogue in the extant mammalian species, but that this morphology was rather more common in the Cretaceous and Palaeocene eutherian mammals (Fabre et al., 2014).

A recent comparative study of faunal similarities or differences between the infratrappean and intertrappean beds has shown that the dinosaurs survived the early phase of volcanism though decreased in diversity and freshwater fauna was least affected by the initial volcanic eruptions (Prasad and Sahni, 2014). It was further observed that detritusfeeding freshwater vertebrate communities fared better than the terrestrial communities during the Deccan volcanism. As compared to dinosaur eggshells, the crocodilian and turtle eggshells are scarcely known from the Upper Cretaceous rocks of India. With the help of eggshell ultrastructure, Prasad et al. (2015) identified eggshells belonging to oofamilies Testudooolithidae and Krokolithidae in the vertebrate fauna of Kisalpuri intertrappean beds, Central India.
As compared to the extensive work carried out on the Upper Cretaceous infra- and intertrappean beds in the last three decades, vertebrate palaeontological research was initiated on the continental Upper Cretaceous Kallamedu Formation of Cauvery basin only recently. Prior to these recent studies, presence of fragmentary and poorly preserved dinosaur bones was noted by Matley (1929). The Kallamedu vertebrate fauna is not as diverse and abundant as that of the Deccan intertrappean beds, nevertheless added many new vertebrate groups to the Late Cretaceous vertebrate fossil list of India. The discovery of a troodontid dinosaur tooth from the Kallamedu Formation assumes great significance from palaeobiogeographic point of view. The presence of this typical Laurasian dinosaur in an essentially Gondwanan faunal assemblage at a time India was far to the south of Laurasian landmasses raises the question of whether troodontid dinosaurs migrated from Laurasia to India in the Late Cretaceous or this group was broadly distributed in the former Gondwanaland (Goswamiet al., 2013). Prasad et al. (2013) described a vertebrate assemblage consisting of remains of fishes, amphibians, turtles, crocodiles and dinosaurs from the Kallamedu Formation. The dinosaur teeth representing abelisaurid dinosaurs seem to have a pan-Gondwanan distribution during the Cretaceous. The presence of Simosuchus-like notosuchian crocodile, the only known occurrence outside Madagascar, however, attests to a close biogeographic link between India and Madagascar in the Late Cretaceous (Maastrichtian). Very recently, Halliday et al. (2016) described phyllodontid fish Egertonia, a taxon with a primarily Laurasian distribution and only the second Cretaceous Gondwanan occurrence of this taxon from the Kallamedu Formation. Sister group relationships are known to exist between abelisaurid dinosaur fauna, bothremydid turtles, madtsoid and nigerophiid snakes, and gondwanathere mammals of India and Madagascar (see Prasad et al., 2013). Simosuchuslike crocodiles and Egertonia further add to the list of growing number of taxa common to Madagascar and India. Since India was separated from Madagascar by a wide ocean in the Late Cretaceous the common occurrence of closely related taxa raises the question on their evolution and dispersal in the Gondwanan continents. Future research should ascertain whether these common taxa were widely 
distributed in the former Gondwanaland and the latter's break-up led to the observed Late Cretaceous distribution under vicariant mode of evolution or whether there were some intermittent Late Cretaceous land bridges between India and Madagascar/South America.

\section{Pre- and Post-collision Phase}

Significant advances have been made during the past few years on the Eocene vertebrate faunas of India, especially mammals. These finds, documented mainly from the early Eocene Cambay Shale Formation of the well known Vastan Lignite Mine in District Surat (Gujarat), middle Eocene Harudi Formation of District Kutch (Gujarat), and from the Subathu Formation of NW Himalaya in the states of Jammu \& Kashmir and Himachal Pradesh, testify to the importance of India as an important centre for the differentiation and dispersal of several major vertebrate groups. These finds also assume significance in the context of India's collision with Asia around the PaleoceneEocene boundary and the resultant faunal exchanges with Eurasia (e.g. Bajpai, 2009).

Recently, the oldest South Asian tapiroid from India has been described by Kapur and Bajpai (2015a, b) from the early Eocene ( $54-55 \mathrm{Ma})$ Cambay Shale at Vastan lignite mine, Gujarat. This new taxon (Cambaylophus vastanensis), which is based on a well preserved partial maxilla with molars and deciduous premolars, appears to show close phylogenetic relationships to the early Eocene tapiromorph Gandheralophus from Pakistan and is closely nested with the early Eocene (Bumbanian) tapiromorph Orientolophus from China. This new study clearly highlights the importance of Cambaylophus in evaluating the evolutionary relationships during the early radiation of tapiromorphs and suggests a degree of terrestrial connectivity between the Indian Subcontinent and the Asian landmass around the time of India-Asia collision, at or near the Paleocene-Eocene boundary $(\sim 55 \mathrm{Ma})$. Subsequently, Smith et al. (2015) also described a tapiroid from Vastan based on two isolated teeth, including a fragmentary premolar. Recent records of early Eocene mammals from Vastan also include a tillodont Anthraconyx hypsomylus that is interpreted to indicate Euroamerican affinities (Rose et al., 2013). Also reported recently (Rana et al., 2015) is the additional dental and postcranial material of Indohyaenodon raoi, the only known mammalian carnivore from Vastan which was originally described on the basis of several dentaries (Bajpai et al., 2009a).

Cooper et al. (2014), based on a detailed morphological and phylogenetic study, concluded that the anthracobunids, a long known group of ungulate mammals from the Indian subcontinent, are actually stem perissodactyls, the mammal order that includes modern horses and rhinos. Prior to this finding, anthracobunids were traditionally considered to be tethytheres, i.e. a group that is closely tied to the origin of elephants. Cooper et al.'s (2014) study is based on anthracobunid fossils comprising dental, cranial and postcranial remains including those from the Kalakot locality, Jammu \& Kashmir. Interestingly, Cooper et al. (2014) reconfirmed that cambaytheres, a new family named and identified as perissodactyls by Bajpai et al. (2005), are a stem group to the mammal order Perissodactyla. In a similar finding, Rose et al. (2014) also favoured perissodactyl affinities of cambaytheres although they had initially disputed their assignment to Perissodactyla and instead referred them to tethyheres (anthracobunids). Cooper et al. (2014) also conducted studies on oxygen and carbon stable isotopes and the long bone geometries of the Eocene anthracobunids and cambaytheres and concluded that they fed on land but also spent time in the water, similar to modern rhinos. Overall, this new study has led to the identification of an Old World radiation of large, non-cursorial, partly aquatic perissodactyls that convergently came to occupy a basal tethythere-like niche on the northern coast of the Tethys Sea. The study not only expands our understanding of stem perissodactyl diversity but also lends support to the possible Out-of-India hypothesis for their origin.

Gupta and Kumar (2015) recently reviewed the Eocene rodent fauna of the Indian subcontinent and also described a small, new assemblage of early Eocene (late Ypresian) rodents from the type Subathu Formation, Himachal Pradesh, NW Himalaya. It is intriguing that ailuravine rodents (Meldimys musak), a European group purportedly recorded from the early Eocene Cambay Shale of Vastan mine (Rana et al. 2008) is completely absent from the nearly contemporary or slightly younger Himalayan Eocene assemblages. Furthermore, it is to be noted, as also 
suggested by Gupta and Kumar (2015), that Meldimys musak is hardly distinguishable from Anthramys vastani described as a ctenodactyloid (family indet.) by Bajpai et al. (2007) and that M. musak may turn out to be a junior synonym of the latter species.

Among the early Eocene lower vertebrate faunas from India, mention may be made of assemblages of frogs, lizards and birds from the Vastan section (Bajpai and Kapur, 2008; Prasad and Bajpai, 2008; Folie et al. 2013; Mayr et al. 2013; Rana et al. 2013). Folie et al.'s (2013) study of fossil frogs includes the families Pelobatidae and Rhacophoridae and compliments an earlier record of ranoid and discoglossid frogs from the same section by Bajpai and Kapur (2008). Paleobiogeographically, the presence of ranoids in Vastan supports an out-of-India dispersal pattern (Bajpai and Kapur, 2008). Overall, the anuran fauna from Vastan does not appear support faunal exchanges between India and Europe during the early Paleogene. Lizards in the Vastan fauna, represented mainly by the acrodontan agamids, suggest that some lineages may have been introduced into Laurasia from India, possibly during one of the several trans-Tethyan dispersal phases (Prasad and Bajpai, 2008). Additional acrodont lizards have since been described from Vastan by Rana et al. (2015). Also described recently from the early Eocene of Vastan are avian remains comprising several skeletal elements of the parrot-like bird Vastanavis with psittaciform affinities (Mayr et al. 2013).

The middle Eocene vertebrate record of the Indian subcontinent continues to provide critical insights into the origin of whales from a four-footed land animal (Indohyus), and this evolutionary change has now become one of the best understood examples of biological macroevolution that involved a drastic transition from land to sea. This major evolutionary event, which involved a number of organ systems, has been documented on the basis of a diverse assemblage of well preserved fossils discovered in the Eocene sections of Kutch (Gujarat) and the Himalayas (e.g. Thewissenet al. 2007; Bajpai et al. 2009b). In an important recent contribution (Cooper et al. 2012), a comparative morphological analysis of the postcranial elements of Indohyus, archaeocetes and extant artiodactyls, provides new insights into the aquatic and terrestrial locomotor affinities of the raoellid Indohyus, filling a critical gap in our understanding of the earliest part of the artiodactyl marine invasion. This study was based on over 200 postcranial fossils of Indohyus recovered from the Kalakot section of Jammu \& Kashmir state. In another important work related to the evolutionary change from herbivory and omnivory to carnivory as reflected in the dental morphology, Thewissen et al. (2011) studied the wear facets, together with dental morphology and stable isotope ecology, across the artiodactyl-cetacean transition. This study found that the artiodactyls Indohyus, the closest known terrestrial relative of whales (Cetacea), had a tooth crown morphology very different from that of Eocene cetaceans, but with wear facets that are closer to those of Eocene cetaceans rather than to the facets of basal artiodactyls. This was a significant observation as it suggested that evolutionary changes in the masticatory function occurred prior to changes in crown morphology and diet at the origin of whales (Thewissen et al., 2011).

Younger and evidently more marine whales are known from the well dated middle Eocene ( 42 Ma) rocks of Kutch, Gujarat. Recently, an excellently preserved skull of an archaic cetacean Remingtonocetus harudiensis from Kutch was described in considerable detail (Bajpai et al. 2011). This study, which also included reconstruction of the cranial cavity based on serial CT-scans, has significantly improved our understanding of the biology of remingtonocetids, a basal family of Eocene cetaceans that lived in muddy coastal, salt- or brackish water swamps of the Indian subcontinent. A recent study has also identified, for the first time, a diverse protocetid fauna from the middle Eocene of Kutch (Bajpai and Thewissen, 2014). The Kutch protocetids, which comprise a variety of genera (Indocetus ramani, Babiacetus indicus, B. mishrai, Kharodacetus sahnii and Dhedacetus hyaeni) with different ecological specializations, were rarer in abundance than the contemporaneous remingtonocetids. The protocetids fed higher up the food chain, although differences in tooth and jaw morphology and dental wear point to a range of diets and food processing abilities (Bajpai and Thewissen, 2014). Interestingly, Kharodacetus is the largest protocetid from Kutch and may have fed on the largest prey such as the catfish, crocodiles and remingtonocetid cetaceans. 
In recent years, the subject of whale evolution has also been studied from a developmental perspective in conjunction with the fossil data. Unlike most mammals, precise occlusion has been secondarily lost in cetaceans, and their fossil record allows an understanding of the timing of the macroevolutionary events leading to their unusual dental morphology. In an important recent study (Armfield et al. 2013), it was suggested that a primitive pattern of rostral Bmp4 and distal $F g f 8$ expression across mammals was modified during cetacean evolution allowing a caudal expansion of Bmp4 expression in the jaw that led to the extra teeth with simple, similar crowns seen in living toothed whales. These authors hypothesized that functional constraints underlying mammalian occlusion have been released in cetaceans, facilitating changes in the genetic control of early dental development.

\section{Summary}

The foregoing discussion on the vertebrate faunas of different phases of India's northward flight brings out clearly that during the pre-drift phase, as contrasted to previous works that focused mostly on nondinosaurian reptilian fauna, the recent studies have substantially enhanced the diversity of dinosaur fauna from Upper Triassic and Lower Jurassic formations. Furthermore, this fauna suggests close biogeographic affinities with the Gondwanan continents and Europe. The first confirmed foot prints of dinosaurs were also documented from marine Jurassic rocks of Jaisalmer area. The fossil record of Jurassic mammals has also improved considerably with the discoveries of multituberculate, haramiyid, triconodont, symmetrodont, docodont and dryolestid mammals from the Kota Formation. Though these mammalian groups do not occur in great abundance, their diversity parallels that of the Laurasian continents. As compared to the fairly well documented fossil record of the pre-drift phase, the vertebrate fossil record for the early drift phase is very scanty, with only a few reports of shark remains coming from the marine Cretaceous sequences of the Cauvery basin.

The Late Drift and Pre-collision phases are the most extensively investigated time slices that attracted more attention because of their association with Cretaceous/Palaeogene (K/Pg) boundary mass extinction and the Palaeocene-Eocene Thermal Maxima (PETM), respectively. The Late Cretaceous fauna from the Deccan volcano-sedimentary sequences has been extensively studied in the last three decades as a consequence of which all the vertebrate groups with the exception of birds have been documented. Recent initiatives to unravel the vertebrate fauna of the Kallamedu Formation have also proved promising, with many new taxa being added to the Late Cretaceous faunal list from this formation. These studies have offered new insights into the mode of evolution of vertebrates during the physical isolation of India from all other landmasses. The common occurrence of bothremydid turtles, abelisaurid dinosaurs, notosuchian crocodiles and gondwanathere mammals in South America, Antarctica, Madagascar and India, and the close phylogenetic relationship between the representative species of these groups in India and Madagascar points to possible vicariant evolution of these groups following the break-up of former Gondwanaland. Furthermore, indigenous origination of certain groups, such as adapisoriculid mammals (Deccanolestes), and their subsequent dispersal to Africa and Europe has also been visualized (Prasad et al., 2010; Smith et al., 2010; Goswami et al., 2011).

Recent studies on stratigraphic units that correspond to pre-collision and post-collision phase, such as the Lower Eocene Cambay Shale of Vastan lignite mine, led to the discovery of the oldest Cenozoic vertebrate assemblage of South Asia. An exceptionally rich assemblage of mammals represented by more than 10 orders has been documented from this formation. Latest research has unambiguously shown that cambaytheres, the stem perissodactyls had originated in India. In addition to this, the oldest tapiroids and lagomorphs, and Gondwanan ranoid frogs and acrodont lizards which attest to 'out of India' dispersal hypothesis, have also been recorded from the Cambay Shale. From the Middle Eocene, the recent work on the transition from terrestrial to aquatic locomotion as well as on dental adaptations among raoellid artiodactyls and early cetaceans has significantly improved our understanding of early stages of whale evolution in the Indian subcontinent. Efforts are also being made to understand whale evolution in a developmental (evo-devo) perspective. 


\section{Concluding Remarks}

Summing up, significant advances have been made in recent years to understand the vertebrate evolution in India in a plate tectonic framework, particularly from the Upper Cretaceous and Eocene deposits of India. This research needs to be undertaken more vigorously in future as it is expected to throw up many new questions and surprises from time to time that will have an important bearing on our understanding of the origin, evolution and dispersal of the various groups of vertebrates. Furthermore, it is important to fill the existing gaps in the vertebrate record,

\section{References}

Armfield B A, Zheng Z, Cohn MJ, Bajpai S, Vinyard C J and Thewissen J G M (2013) Development And Evolution of The Unique Cetacean Dentition Peer J (http://dx.doi.org/ 10.7717/peerj.24)

Bajpai S (2009) Biotic perspective of the Deccan volcanism and India-Asia collision: Recent advances. In: Current trends in Science, Platinum Jubilee Special publication Indian Acad Sci 505-516

Bajpai S and Kapur V V (2008) Earliest Cenozoic frogs from the Indian subcontinent: Implications for out-of-India hypothesis Journal of the Palaeontological Society of India 53 65-71

Bajpai S and Thewissen J G M (2014) Protocetid cetaceans (Mammalia) from the Eocene of India Palaeontologia Electronica 17.3.34A

Bajpai S, Thewissen J G M and Conley R W (2011) Cranial anatomy of middle Eocene Remingtonocetus (Cetacea, Mammalia) from Kutch, western India J Paleontol $85705-$ 720

Bajpai S, Kapur V V and Thewissen J G M (2009a) Creodont and condylarth from Cambay Shale (early Eocene, 55-54 Ma), Vastan Lignite Mine, Gujarat, western India Journal of the Palaeontological Society of India 54 103-109

Bajpai S, Thewissen J G M and Sahni A (2009b) The origin and early evolution of whales: Macroevolution documented on the Indian Subcontinent Journal of Biosciences 34 673686

Bajpai S, Kapur V V, Das D P, Tiwari B N, Saravanan N and Sharma R (2005) Early Eocene land mammals from Vastan lignite mine, District Surat (Gujarat), western India Journal of the Palaeontological Society of India 50 101-113 specifically from the Palaeocene which is a critical period for a better understanding of the evolutionary trajectories from the Cretaceous to the Eocene.

\section{Acknowledgements}

GVR Prasad acknowledges DST, New Delhi for JC Bose National Fellowship. Sunil Bajpai acknowledges financial support from the Department of Science and Technology, Government of India. We are thankful to Dr. Arjun Singh Rathore, Department of Geology, Delhi University for his help in typesetting the manuscript.

Bajpai S, Das D P, Kapur V V, Tiwari B N and Srivastava S S (2007) Early Eocene rodents (Mammalia) from Vastan lignite mine, Gujarat, western India Gondwana Geological Magazine 22 91-95

Baksi S K (1973) Fossil fish from coastal Gondwana Raghavapuram Mudstone, West Godavari District, Andhra Pradesh, India Proc Indian Natl Sci Acad Pt A: Phys Sci 38 $32-44$

Bandyopadhyay S, Gillette D D, Ray S and Sengupta D P (2010) Osteology of Barapasaurus tagorei (Dinosauria: Sauropoda) from the Early Jurassic of India Palaeontology $53533-569$

Bossuyt F and Milinkovitch M (2001) Amphibians as indicators of early Tertiary "out-of-India" dispersal of vertebrates Science 292 93-95

Boyer D, Prasad G V R, Krause D W, Godinot M, Goswami A, Verma O and Flynn J J (2010) New postcrania of Deccanolestesfrom the Late Cretaceous of India and their bearing on the evolutionary and biogeographic history of euarchontan mammals Naturwissenschaften 97 365-377

Chatterjee S, Goswami A and Scotese C R (2013) The longesrt voyage: Tectonic, magmatic and paleoclimatic evolution of the Indian plate during its northward flight from Gondwana to Asia Gondwana Res 23 238-267

Cooper L N, Thewissen J G M, Bajpai S and Tiwari B N (2012) Morphology and locomotion of the Eocene raoellid Indohyus (Artiodactyla: Mammalia) Historical Biology 24 279-310

Cooper L N, Seiffert E R, Clementz M, Madar S I, Bajpai S, Hussain S T, Thewissen J G M (2014) Anthracobunids from the Middle Eocene of India and Pakistan Are Stem Perissodactyls PLOS ONE 9 e109232. doi:10.1371/ journal.pone.0109232 
Fabre Anne-Claire, Cornette R, Boyer D B, Prasad G V R, Hooker $\mathrm{J}$ and Goswami A(2014) A three-dimensional morphometric analysis of the locomotory ecology of Deccanolestes, a eutherian mammal from the late Cretaceous of India $J$ Vertebr Paleontol 34 146-156

Fernández M S and Khosla A (2015) Parataxonomic review of the Upper Cretaceous dinosaur eggshells belonging to the oofamily Megaloolithidae from India and Argentina Historical Biology 27 158-180

Folie A, Rana R S, Rose K D, Sahni A, Kumar K, Singh L and Smith T (2013) Early Eocene frogs from Vastan Lignite Mine, Gujarat, India Acta Palaeontol Pol 58 511-524

Gheerbrant E and Russell D E (1989) Presence of the genus Afrodon (Mammalia, Lipotyphla(?) Adapisoriculidae) in Europe; new data for the problem of trans-Tethyan relations between Africa and Europe around the K/T boundary Palaeogeogr Palaeoclimatol Palaeoecol 76 115

Gupta A and Das D P (2011) Report of Lystrosaurus cf. curvatus and $L$. cf. declivis from the Early Triassic, Panchet Formation, Damodar Valley, West bengal, India and its implication Indian Journal of Geosciences 65 119-130

Gupta S and Kumar K (2015) Early Eocene rodents (Mammalia) from the Subathu Formation of type area (Himachal Pradesh), NW sub-Himalaya, India: Palaeobiogeographic implications J Earth Syst Sci 124 1201-1221

Goswami A, Prasad G V R, Upchurch P, Boyer D M, Seiffert E R, Verma O, Gheerbrant E and Flynn J J (2011) A radiation of arboreal basal eutherian mammals beginning in the Late Cretaceous of India Proc Natl Acad Sci USA $10816333-$ 16338

Goswami A, Prasad G V R, Verma O, Flynn J J and Benson R B J (2013) A troodontid dinosaur from the latest Cretaceous of India Nature Communications 4:1703 doi:10.1038/ ncomms2716/www.nature.com/naturecommunications

Halliday T H D, Cuff A R, Prasad G V R, Thanglemmoi M S and Goswami A (2016) New record of Egertonia (Elopiformes, Phyllodontidae) from the Late Cretaceous of South India Papers Palaeontol 1-8

Jain S L, Kutty T S, Roychowdhury T and Chatterjee S (1979) Some characteristics of Barapasaurus tagorei, a sauropod dinosaur from the Lower Jurassic of Deccan, India IVth International Gondwana Symposium, Calcutta $1204-216$

Kapur V V and Bajpai S (2015a) New data on basal Eocene land mammal fauna from western India: Focus on Perissodactyls. National Conference on "Palaeogene of the Indian Subcontinent", Lucknow, April 23-24, 2015, Abstract Volume 55-56
Kapur V and Bajpai S (2015b) Oldest South Asian tapiromorph (Perissodactyla, Mammalia) from the Cambay Shale Formation, western India, with comments on its phylogenetic position and biogeographic implications Palaeobotanist 64 95-103

Khosla A, Chin C, Alimohammadin H and Dutta D (2015) Ostracods, plant tissues, and other inclusions in coprolites from the Late Cretaceous Lameta Formation at Pisdura, India: taphonomical and palaeoecological implications Palaeogeogr Palaeocl 418 90-100

Krause D W and Maas M C (1990) The biogeographic origins late Paleocene-early Eocene mammalian immigrants to the Western Interior of North America In: Dawn of the age of mammals in the northern part of the Rocky Mountain Interior, North America (Eds: Bown T M and Rose K D) pp 71-105 Geol Soc Amer Sp Paper 243

Kutty T S, Chatterjee S, Galton P and Upchurch P (2007) Basal sauropodomorphs (Dinosauria: Saurischia) from the Lower Jurassic of India: Their anatomy and relationships $J$ Paleontol 81 1218-1240

McLean, D M (1985) Deccan Traps mantle degassing in the terminal Cretaceous mass extinctions Cretaceous Res 6 235-259

Matley CA (1929) The Cretaceous dinosaurs of the Trichinopoly district and the rocks associated with them Rec Geol Surv India 61 337-349

Mayr G, Rana R S, Rose K D, Sahni A, Kumar K and Smith $\mathrm{T}$ (2013) New Specimens of the Early Eocene Bird Vastanavis and the Interrelationships of Stem Group Psittaciformes Paleontological J 47 1308-1314

Mohabey D M, Head J J and Wilson J A (2011) A new species of the snake Madtsoia from the Upper Cretaceous of India and its paleobiogeographic implications $J$ Vertebr Paleontol 31 588-595

Mukherjee D (2015) New insights from bone microanatomy of the Late Triassic Hypeodapedon (Archosauromorpha, Rhynchosauria): implications for archosauromorphs growth strategy Palaeontology 58 313-339

Mukherjee D and Ray S (2012) Taphonomy of an Upper Triassic vertebrate bone bed: A new rhynchosaur (Reptilia; Archosauromorpha) accumulation from India Paleogeogr Palaeoecol 333-334 75-91

Mukherjee D and Ray S (2014) A new Hyperodapedon (Archosauromorpha, Rhynchosauria) from the Upper Triassic of India: implications for rhynchosaur phylogeny Palaeontology 57 1241-1276

Novas F E, Ezcurra M D, Chatterjee S and Kutty T S (2011) New dinosaur species from the Upper Triassic Upper 
Maleri and Lower Dharmaram formations of Central India

Earth and Environmental Science Transactions of the Royal Society of Edinburgh 101 333-349

Parmar V, Prasad G V R and Kumar D (2013) The first multituberculate mammal from India Naturwissenschaften $100515-523$

Parmar V, Prasad G V R and Kumar D (2015) An overview of Jurassic mammalian fauna of India. Abstracts of the $12^{\text {th }}$ Symposium on Mesozoic Terrestrial Ecosystems 18-20, Shenyang, China

Patriat P and Achache J (1984) India-Eurasia collision chronology has implications for crustal shortening and driving mechanism of plates Nature 311 615-621

Pienkowski G, Branski P, Pandey D K, Schlgöl J, Alberti M and Fürsich F T (2015) Dinosaur footprints from the Thaiat ridge and their palaeoenvironmental background, Jaisalmer basin, Rajasthan, India Volumina Jurassica XIII 17-26

Powell C Mc A (1979) A speculative tectonic history of Pakistan and surroundings: Some constraints from the Indian Ocean. In: Geodynamics of Pakistan (Eds: Farah A and Jong De KA) pp 5-24, Geological Survey of Pakistan

Prasad G V R (2012) Vertebrate biodiversity of the Deccan volcanic province of India: A review Bull Geol Soc France $183597-610$

Prasad G V R and Bajpai S (2008) Agamid lizards from the early Eocene of western India: oldest Cenozoic lizards from South Asia Palaeontologia Electronica $1119 \mathrm{p}$

Prasad G V R and Godinot M (1994) Eutherian tarsal bones from the Late Cretaceous of India J Paleontol 68 892-902

Prasad G V R and Manhas B K (2007) A new docodont mammal from the Jurassic Kota Formation of India Palaeontologa Electronica 107A:11P

Prasad G V R, Manhas B K and Arratia G (2004) Elasmobranch and actinopterygian remains from the Jurassic and Cretaceous of India. In: Mesozoic Fishes 3 - Systematics, Paleoenvironments and Biodiversity, (Eds: Arratia G and Tintori A) pp 625-638, Verlag Dr. Friedrich Pfeil, (München, Germany)

Prasad G V R and Sahni A (1999) Were there size constraints on biotic exchanges during the northward drift of the Indian plate? In: Gondwana assembly: new issues and perspectives (Eds: Sahni A and Loyal RS) Proc Ind Nat Sci Acad A3 377-396

Prasad G V R and Sahni A (2014) Vertebrate fauna from the Deccan volcanic province:Response to volcanic activity. In: Volcanism, Impacts, and Mass Extinctions: Causes and Effects (Eds: Keller G and Kerr AC) Geol Soc Am Spl
Paper 505 1-18

Prasad G V R, Sharma A, Verma O, Khosla A, Lourembam R S and Priyadarshini R K (2015) Testudoid and crocodiloid eggshells from the Upper Cretaceous Deccan intertrappean beds of Central India Compt Rend Palevol 14 513-526

Prasad G V R, Verma O, Flynn J J and Goswami A (2013) A new Late Cretaceous vertebrate fauna from the Cauvery basin, South India: Implications for Gondwanan palaeobiogeography $J$ Vertebr Paleontol 33 1260-1268

Prasad G V R, Verma O, Gheerbrant E, Goswami A, Khosla A, Parmar V and Sahni A (2010) First mammal evidence from the Late Cretaceous of India for biotic dispersal between India and Africa at the $\mathrm{K} / \mathrm{T}$ transition Compt Rend Palevol $963-71$

Rana R S, Kumar K, Escarguel G, Sahni A, Rose K D, Smith T, Singh $\mathrm{H}$ and Singh L (2008) An ailuravine rodent from the lower Eocene Cambay Formation at Vastan, western India, and its palaeobiogeographic implications Acta Palaeontol Pol 53 1-14

Rana R S, Auge M, Folie A, Rose K D, Kumar K, Singh L, Sahni A and Smith T (2013) High diversity of acrodontan lizards in the Early Eocene Vastan Lignite Mine of India Geol Belg 16 290-301

Rana R S, Kumar K, Zack P S, Solé F, Rose K D, Missiaen P, Singh L, Sahni A and Smith T (2015) Craniodental and postcranial morphology of Indohyaenodon raoi from the early Eocene of India, and its implications for ecology, phylogeny,and biogeography of hyaenodontid mammals $J$ Vertebr Paleontol doi: 10.1080/02724634.2015.965308

Ray S (2015) A new Late Triassic traversodontid cynodont (Therapsida, Eucynodontia) from India $J$ Vertebr Paleontol 35 e930472 DOI: 10.1080/02724634.2014.930472

Rose K D, Kumar K, Rana R S, Sahni A and Smith T (2013) New hypsodont tillodont (Mammalia, Tillodontia) from the Early Eocene of India Journal of Palaeontology 87 842853

Rose K D, Holbrook L T, Rana R S, Kumar K, Katrina E J, Heather E S, Missiaen P, Sahni A and Smith T (2014) Early Eocene fossils suggest that the mammalian order Perissodactyla originated in India Nature communications 5 1-9

Russell D E (1964) Les mammifères paléocène d'Europe Mem Mus Nat Hist Natur Ser C 13 1-324

Smith T, Sigé B and De Bast E (2010) Euarchontan affinity for the Palaeocene Afro-European adapisoriculid mammals and their origin in the late Cretaceous Deccan Traps of India Naturwissenschaften 9 7417-422 
Smith T, Solé F, Missiaen P, Rana R S, Kumar K, Sahni A and Rose K D (2015a) First early Eocene tapiroid from India and its implication for the paleobiogeographic origin of perissodactyls Palaeovertebrata 39 e5

Srivastava A K and Mankar R S (2015) Megaloolithus dinosaur nest from the Lameta Group of Salbardi area, Districts Amaravati, Maharashtra and Betul, Madhya Pradesh $J$ Geol Soc India $\mathbf{8 5}$ 457-462

Srivastava R, Patnaik R, Shukla U K and Sahni A(2015) Crocodilian nest in a Late Cretaceous sauropod hatchery from the type Lameta Ghat locality, Jabalpur, India PLOS ONE10 / e0144369. DOI: 10.1371/journal.pone.0144369

Thewissen J G M, Cooper L N, Clementz M T, Bajpai S and Tiwari B N (2007) Whales originated from aquatic artiodactyls in the Eocene epoch of India Nature 4501190 1194

Thewissen J G M, Sensor J D, Clementz M and Bajpai S (2011) Evolution of dental wear and diet during the origin of whales Paleobiology 37 655-669
Underwood C J, Goswami A, Prasad G V R, Verma O and Flynn J J (2011) Marine vertebrates from the 'middle' Cretaceous (Early Cenomanian) of South India J Vertebr Paleontol 31 539-552

Veevers J J, Powell C McA and Roots D (1991) Review of seafloor spreading around Australia, I: Synthesis of the pattern of spreading Aust J Earth Sci 38 373-389

Verma O, Prasad G V R, Goswami A and Parmar V (2012) Ptychodus decurrens Agassiz (Elasmobranchii: Ptychodontidae) from the Upper Cretaceous of India Cretaceous Res 33 183-188

Wilson J A, Mohabey D M, Peters S E and Head J J (2010) Predation upon hatchling dinosaurs by a new snake from the Late Cretaceous of India PLoS Biol 8 e1000322 doi: 10.1371/journal.pbio.1000322

Yadagiri P, Prasad K N and Satsangi P P (1979) The sauropod dinosaur from Kota Formation of Pranhita-Godavari valley, India IVth International Gondwana Symposium, Calcutta 1 199-203. 